\title{
Keragaan Agronomis dan Kelayakan Usahatani Kedelai yang Dibudidayakan Secara Monokultur dan Polikultur di Sumatera Selatan
}

\author{
Agronomic and Economic Analysis of Soybeans which is Grew by Monoculture and \\ Polyculture Systems in South Sumatra
}

\author{
Renny Utami Somantri ${ }^{1 *}$, Syahri Syahri ${ }^{1}$, Tumarlan Thamrin ${ }^{1}$ \\ ${ }^{1}$ Balai Pengkajian Teknologi Pertanian (BPTP), Sumatera Selatan 30151 \\ Penulis untuk korespondensi: rennuta@gmail.com
}

(diterima 12 Juni 2019, disetujui 25 Juli 2019)

Sitasi: Somantri RU, Syahri S, Thamrin T. 2019. Agronomic and economic analysis of soybeans which is grew by monoculture and polyculture systems in South Sumatra. Jurnal Lahan Suboptimal: Journal of Suboptimal Lands. 8(2): 159-172.

\begin{abstract}
The presence of shade and other limiting factors in the crops of plantation plants will certainly affect the growth and soybean yield were compared by monoculture. The objective of the research was to know of agronomic performance and farming feasibility of soybeans which are cultivated by polyculture and monoculture systems. Soybeans were planted in two systems namely monoculture (soybean) and polyculture (soybean are intercropped with 3 years of rubber trees). Both of Dena 1 and Anjasmoro varieties were cropped in those systems. Soybeans are cropped by using planting machine (ATBJ) which has planting distance $20 \mathrm{~cm}$ x $40 \mathrm{~cm}$ (1-2 seeds per hole). Plants were fertilized with $50 \mathrm{~kg}$ Urea per ha, $150 \mathrm{~kg}$ TSP per ha, $150 \mathrm{~kg} \mathrm{KCl}$ per ha, manure 2,000 $\mathrm{kg}$ per ha, and dolomite $1,000 \mathrm{~kg}$ per ha. Mower were used for harvesting. The results showed that the growth and soybean yield in monoculture system was better than the polyculture. Yield of Anjasmoro in monoculture was $15.35 \mathrm{ku}$ per ha, whereas the polyculture was $4.72 \mathrm{ku}$ per ha. Meanwhile, the productivity of Dena 1 was $14.80 \mathrm{ku}$ per ha and $7.38 \mathrm{ku}$ per ha in polyculture system. The polyculture had a higher value of the land equivalent ratio than monoculture of rubber trees. Economically, the two planting systems that were examined also deserve to be done by farmers, where the value R/C $>1$.
\end{abstract}

Keywords: agronomic performance, economic analysys, monoculture, polyculture soybean

\begin{abstract}
ABSTRAK
Pengaruh naungan dan faktor pembatas lainnya pada gawangan tanaman perkebunan akan berpengaruh terhadap pertumbuhan dan hasil kedelai dibandingkan penanaman monokultur. Kajian ini bertujuan untuk mengetahui keragaan agronomis dan kelayakan usahatani kedelai yang dibudidayakan secara monokultur dan polikultur. Kajian menggunakan RAK 2 Faktor dengan 2 ulangan. Faktor pertama yang dikaji meliputi pola tanam (monokultur dan polikultur), dan faktor kedua yaitu VUB kedelai (Dena 1 dan Anjasmoro). Teknologi yang diterapkan untuk perlakuan tersebut sama yaitu mengikuti Pengelolaan Tanaman Terpadu. Penanaman dilakukan menggunakan alat tanam biji-bijian (ATBJ) dengan jarak tanam $20 \mathrm{~cm}$ x $40 \mathrm{~cm}$ (1-2 biji per lubang tanam). Hasil kajian
\end{abstract}


menunjukkan keragaan pertumbuhan dan hasil kedelai dengan pola monokultur lebih baik dibanding dengan polikultur. Produktivitas kedelai varietas Anjasmoro pertanaman monokultur mencapai $15,35 \mathrm{ku} / \mathrm{ha}$, sedangkan dengan polikultur hanya menghasilkan biji kedelai 4,72 ku/ha. Sementara itu, produktivitas kedelai varietas Dena 1 sebesar 14,80 $\mathrm{ku} / \mathrm{ha}$ dan dengan sistem tumpangsari menghasilkan biji kedelai 7,38 ku/ha.Akan tetapi, sistem polikultur memiliki nilai Nisbah Kesetaraan Lahan lebih tinggi dibandingkan dengan pertanaman karet dengan sistem monokultur. Secara ekonomi, kedua pola tanam yang dikaji juga layak untuk dilakukan petani, dimana nilai $\mathrm{R} / \mathrm{C}>1$.

Kata kunci: kedelai, keragaan agronomis, monokultur, polikultur, usahatani

\section{PENDAHULUAN}

Kedelai merupakan salah satu komoditas pangan utama dan menjadi komoditas unggulan yang sangat strategis pada pembangunan perekonomian Indonesia (Zakaria, 2010). Kebutuhan kedelai setiap tahunnya mencapai 1,8 juta ton dan bungkilkedelai 1,1 juta ton dan cenderung meningkat setiap tahunnya sejalan dengan meningkatnya pertumbuhan penduduk. Namun demikian, produksi kedelai dalam negeri barumemenuhi $40 \%$ dari kebutuhan, sisanya sebanyak $60 \%$ dipenuhi dari impor (Taufiq et al., 2009). Hal ini mengindikasikan bahwa Indonesia masih mengalami defisit yang cukup besar dalam memenuhi kebutuhan kedelai.

Pengembangan areal persawahan yang lebih difokuskan untuk padi tentunya mengharuskan pemanfaatan lahan lainnya yang berpotensi untuk pengembangan kedelai. Tanaman kedelai dapat dikembangkan dalam sistem tumpangsari dengan tanaman perkebunan terutama pada lahan bukaan baru maupun pada tahun awal penanaman tanaman perkebunan atau saat peremajaan. Susanto dan Sundari (2010) menyatakan lahan perkebunan dapat dimanfaatkan sebagai lahan tanaman pangan terutama pada tiga tahun pertama.

Salah satu tanaman perkebunan yang berpotensi ditanami kedelai adalah perkebunan karet. Karet merupakan komoditas perkebunan unggulan di Sumatera Selatan, dimana pada tahun 2016 luas perkebunannya mencapai 1,25 juta ha.Peluang pengembangan kedelai di bawah tegakan tanaman karet muda cukup besar. Pada tahun pertama, 70\% luas area karet dapat ditanami dengan tanaman penutup tanah atau tanaman pangan. Sejalan dengan bertambahnya penutupan lahan oleh tajuk, area tersebut berkurang hingga $50 \%$ pada tahun ketiga. Hal ini berarti sampai tahun ketiga, 50-70\% dari luas area tanaman karet yang diremajakan dapat ditanami dengan tanaman pangan (Gunawan, 2005). Menurut Mimbar (1994), penutupan permukaan tanah yang cepat oleh tanaman kedelai dapat mencegah timbulnya erosi dan hilangnya lengas tanah yang berlebihan, dan di waktu yang bersamaan tidak tersisa ruang bagi pertumbuhan gulma karena seluruh ruang di antara barisan-barisan tanaman diduduki oleh tanaman kedelai (Mimbar, 1994). Pada kondisi demikian, penanaman kedelai toleran naungan sebagai tanaman sela merupakan salah satu upaya yang dapat ditempuh. Pola tumpangsari dapat meningkatkan produktivitas lahan dan memberikan hasil langsung kepada petani berupa hasil kedelai. Selain memberikan manfaat dalam peningkatan produktivitas lahan dan hasil langsung ke petani, penanaman kedelai sebagai tanaman sela di bawah tegakan tanaman karet secara tidak langsung akan berdampak terhadap peningkatan produksi kedelai nasional melalui perluasan area tanam.

Namun, terdapat kendala yang utama dalam pengembangan kedelai sebagai tanaman sela diantaranya adalah rendahnya intensitas cahaya akibat faktor naungan (Sopandie et al., 2007). Intensitas cahaya rata-rata berkurang $25-50 \%$ di bawah tegakan karet berumur 2-3 tahun (Chozin et al., 1999). Cahaya matahari dapat mempengaruhi pertumbuhan tanaman 
karena dapat mempengaruhi proses fotosintesis, sehingga berdampak pada kelangsungan hidup tanaman, pertumbuhan dan adaptasi (Janska et al., 2009). Cahaya adalah sumber energi fotosintesis tanaman dan intensitas cahaya memiliki pengaruh penting pada morfologi, fisiologi, dan reproduksi tanaman (Kosma et al., 2013). Untuk mengatasi kendala tersebut maka dibutuhkan vaerietas kedelai yang toleran terhadap naungan. Tujuan penelitian ini dilakukan dalam rangka mengetahui keragaan agronomis dan kelayakan usahatani kedelai yang dibudidayakan secara monokultur maupun sebagai tanaman sela di antara tanaman karet yang belum menghasilkan.

\section{BAHAN DAN METODE}

Kajian dilaksanakan di lahan petani di Kecamatan Talang Ubi Kabupaten Penukal Abab Lematang Ilir (PALI) sejak April hingga Desember 2018. Rancangan kajian menggunakan Rancangan Acak Kelompok (RAK) 2 faktor dengan 2 kelompok. Faktor pertama yang dikaji meliputi pola tanam (monokultur dan polikultur), dan faktor kedua yaitu VUB kedelai (Dena 1 dan Anjasmoro).

Sistem monokultur dilakukan dengan cara menanam kedelai tanpa naungan pada lahan seluas $1.450 \mathrm{~m}^{2}$. Kelompok pertama berada pada sisi selatan lahan, jarak 0-75 m ke arah utara dan kelompok kedua berada pada sisi utara, jarak 80-150 m. Setiap petak perlakuan berukuran $45 \times 75 \mathrm{~m}$. Jarak antara kelompok pada pola tanam monokultur sekitar $5 \mathrm{~m}$. Pola tanam polikultur dilakukan di perkebunan karet seluas $2.100 \mathrm{~m}^{2}$. Perkebunan ditanami karet klon PB260 berumur 3 tahun, dengan jarak tanam 4x5 m (populasi 500/hektar). Kelompok pertama berada pada sisi timur kebun karet, jarak 0-50 m ke arah barat; sedangkan kelompok kedua berada pada jarak 50-100 m. Kebun karet milik kooperator berbatasan dengan jalan kebun selebar $5 \mathrm{~m}$ (timur dan selatan), sedangkan sisi sebelah utara dan barat berbatasan dengan kebun milik petani lain, dengan umur tanaman karet yang sama.

Pola tanam polikultur dilakukan dengan menanam kedelai secara tumpangsari pada gawangan karet besar (5 m), dimana kedelai ditanam $1 \mathrm{~m}$ dari batang karet. Populasi kedelai diperkirakan sebanyak 208 tanaman per $50 \mathrm{~m}$ gawangan. Setiap petak perlakuan berukuran 21 gawangan sepanjang 50 meter. Jarak antara antara lahan yang digunakan untuk pola polikultur dan monokultur sekitar $200 \mathrm{~m}$. Dena 1 merupakan varietas kedelai toleran naungan sampai 50\% dilepas tahun 2014. Anjasmoro dilepas tahun 2001, produktivitas tinggi dan tidak toleran naungan. Teknologi yang diterapkan untuk semua perlakuan sama yaitu mengikuti Pengelolaan Tanaman Terpadu (PTT) kedelai.

Pengolahan tanah dilakukan dengan olah tanah sempurna. Lahan disemprot herbisida terlebih dahulu dan dibajak sebanyak dua kali. Penanaman dilakukan menggunakan alat tanam biji-bijian (ATBJ) dengan jarak tanam $20 \mathrm{~cm}$ x $40 \mathrm{~cm}$ (1-2 biji per lubang tanam). Sebelum ditanam benih terlebih dahulu dicampur Rhizobium dengan dosis $200 \mathrm{~g}$ per $50 \mathrm{~kg}$ benih. Untuk pola tanam tumpangsari, penanaman kedelai dilakukan pada gawangan lebar dari pertanaman karet (jarak $5 \mathrm{~m}$ ) dan ditanam pada jarak sekitar 1 $\mathrm{m}$ dari lilit batang karet.

Dosis pemupukan ditetapkan berdasarkan hasil pengujian tanah menggunakan Perangkat Uji Tanah Kering (PUTK) dimana pupuk Urea yang diberikan sebanyak $50 \mathrm{~kg} / \mathrm{ha}, 150 \mathrm{~kg}$ TSP/ha, $150 \mathrm{~kg}$ $\mathrm{KCl} / \mathrm{ha}$, pupuk kandang 2 ton/ha, dan dolomit 1ton/ha. Pemupukan dilakukan sekali pada saat tanaman berumur 14 hari dengan cara dilarik di antara barisan tanaman.

Pengendalian hama dilakukan melalui penyemprotan insektisida berbahan aktif klorantaniliprol. Hal ini dilakukan karena adanya serangan beberapa hama pemakan daun seperti belalang dan kumbang pemakan daun. Sedangkan, pengendalian gulma di sekitar pertanaman kedelai yakni menggunakan herbisida berbahan aktif 
parakuat diklorida. Panen dilakukan setelah semua daun tanaman sudah tua atau berwarna kuning menggunakan mower yang telah dimodifikasi pisaunya. Setelah dipanen, polong kedelai yang masih melekat di batangnya segera dijemur. Kemudian biji dirontokkan menggunakan thresher kedelai dengan Pengeringan biji dilakukan dengan cara penjemuran sinar matahari.

Data yang dikumpulkan meliputi intensitas cahaya di antara tanaman karet, status hara tanah di lokasi pengkajian dengan menggunakan PUTK, komponen pertumbuhan dan hasil kedelai yang meliputi tinggi tanaman, jumlah polong bernas, jumlah polong hampa, bobot 100 butir, hasil biji per plot. Selain itu, juga dilakukan analisis kelayakan ekonomi budidaya kedelai serta dilakukan pengukuran Nisbah Kesetaraan Lahan (LER-Land Equivalent Ratio) untuk pola tanam polikultur.

Intensitas cahaya di antara tanaman karet diketahui melalui pengukuran menggunakan lightmeter. Pengukuran awal dilakukan pada saat kondisi sinar matahari berada tepat di atas kebun (intensitas cahaya puncak) yakni sekitar jam 11.0012.00 WIB. Pengukuran dilakukan pada beberapa titik yakni jarak 20 m, 40 m, 60 m dan $80 \mathrm{~m}$ dari arah timur ke barat (pada gawangan besar).

LER menggambarkan suatu areal yang dibutuhkan untuk total produksi monokultur yang setara dengan 1 ha produksi tumpang sari. LER dihitung mengikuti prosedur Mead dan Willey (1980) sebagai berikut:

$$
L E R=\frac{Y_{D} \text { tumpangsari }}{Y_{D} \text { monokultur }}
$$

Dimana, $\mathrm{Y}_{\mathrm{D}}=$ Produksi tanaman kedelai

Data yang diperoleh disajikan secara tabulasi dan dirata-ratakan.

\section{HASIL}

\section{Keadaan Iklim di Lokasi Pengkajian}

Badan Pusat Statistik Kab. PALI (2017), menyatakan bahwa curah hujan rata-rata di Kec. Talang Ubi yakni $220,58 \mathrm{~mm}$ per hari dengan hari hujan rata-rata yakni 13 hari per bulan. Ketinggian tempat 24-84 m dpl dan memiliki jenis tanah alluvial dan podsolik merah kuning.Berdasarkan kriteria kesesuaian lahan untuk tanaman kedelai yang dikeluarkan Kementerian Pertanian No.79/Permentan/OT.140/8/2013, FAO (1976) dan Naidu et al. (2006), Kecamatan Talang Ubi cukup sesuai untuk pengembangan kedelai, dimana curah hujan yang dibutuhkan yakni 200-300 mm. Pola curah hujan dan kalender musim tanam di Kecamatan Talang Ubi (Gambar 1).

\section{Intensitas Cahaya di Antara Tanaman Karet}

Terdapat dua kriteria pengukuran cahaya yakni pada kondisi normal (cerah) dan pada kondisi mendung. Pada kondisi cerah intensitas cahaya berkisar antara 10.36468.736 lux, sedangkan pada kondisi mendung yakni 44.806-80.283 lux. Hasil pengukuran terhadap intensitas cahaya (Gambar 2).

\section{Keragaan Agronomis Kedelai pada Pola Monokultur dan Polikultur}

Adapun keragaan pertumbuhan dan hasil kedelai yang ditanam secara monokultur maupun polikultur (Tabel 1). Tabel 1 menunjukkan bahwa tanaman kedelai yang ternaungi tanaman karet umur 3 tahun (polikultur) lebih tinggi dibandingkan dengan pertanaman kedelai secara monokultur, dimana varietas Anjasmoro lebih tinggi $60,6 \%$ dibanding secara monokultur, sedangkan varietas Dena 1 lebih tinggi $76,8 \%$ dibanding varietas sejenis yang ditanam secara monokultur. Hasil kajian memperlihatkan bahwa pada pola polikultur, jumlah polong total dan jumlah polong isi varietas Anjasmoro yang dihasilkan kedelai lebih rendah dibandingkan kedelai yang ditanam secara 
monokultur. Jumlah polong total dan jumlah polong isi kedelai varietas Anjasmoro sistem tumpangsari lebih rendah $42 \%$ dan $45 \%$ dibandingkan sistem monokultur.

Hasil kajian menunjukkan bahwa produksi kedelai yang ditanam polikultur lebih rendah dibandingkan secara monokultur. Hasil biji kering kedelai varietas Anjasmoro pertanaman monokultur mencapai 15,35 ku/ha, sedangkan dengan polikultur hanya menghasilkan biji kedelai $4,72 \mathrm{ku} / \mathrm{ha}$ atau lebih rendah $69,25 \%$. Pertanaman monokultur kedelai varietas Dena 1 menghasilkan biji kering sebanyak $14,80 \mathrm{ku} / \mathrm{ha}$ dan dengan sistem tumpangsari menghasilkan biji kedelai $7,38 \mathrm{ku} / \mathrm{ha}$ atau $50,14 \%$ lebih rendah dibanding pertanaman monokultur (Tabel 1).

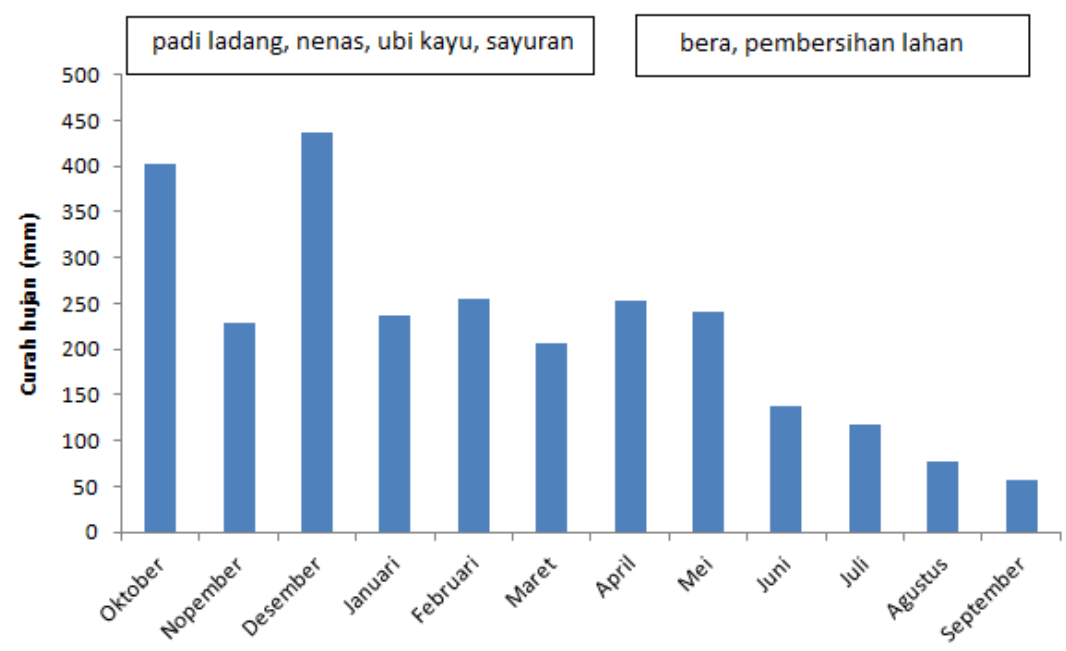

Gambar 1. Pola curah hujan dan kalender musim tanam Kec. Talang Ubi

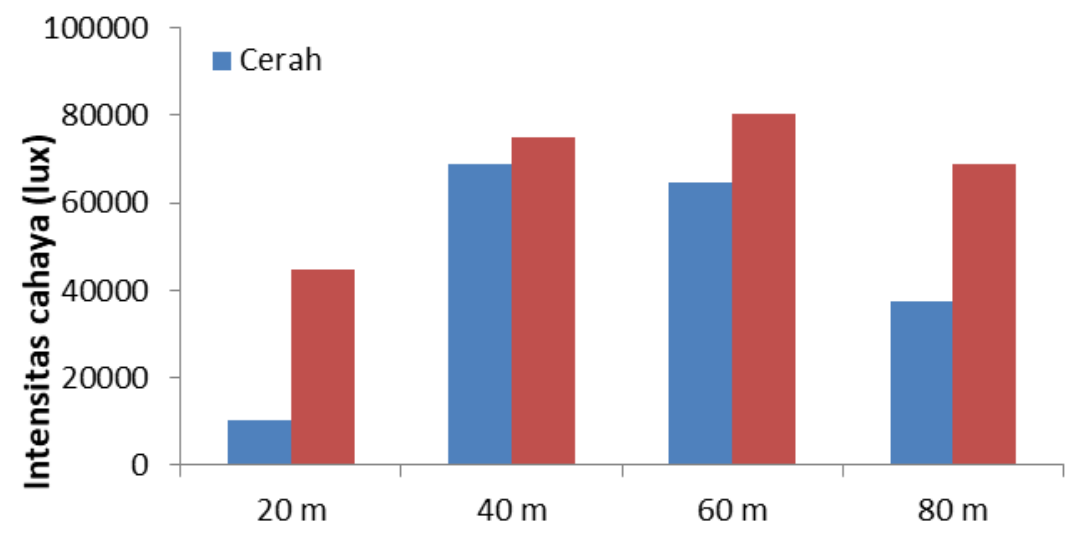

Gambar 2. Intensitas cahaya matahari pada gawangan karet 
Tabel 1. Pertumbuhan dan hasil kedelai pada pola monokultur dan polikultur

\begin{tabular}{lrrrr}
\hline \multirow{2}{*}{ Parameter } & \multicolumn{2}{c}{ Monokultur } & \multicolumn{2}{c}{ Polikultur } \\
\cline { 2 - 5 } & Anjasmoro & Dena 1 & Anjasmoro & \multicolumn{1}{c}{ Dena 1 } \\
\hline Tinggi tanaman (cm) & 51,0 & 44,5 & 81,9 & 78,7 \\
Jumlah cabang utama (cabang) & 7,0 & 3,4 & - & - \\
Jumlah buku subur (buku) & 17,0 & 17,4 & - & - \\
Jumlah polong total per tanaman & 69,4 & 40,9 & 40,0 & 42,0 \\
Jumlah polong isi per tanaman & 69,4 & 40,24 & 38,0 & 41,0 \\
Jumlah Polong hampa per tanaman & 0 & 2,4 & 2,0 & 2,0 \\
Bobot 100 butir (g) & - & 16 & 16,5 & 16,0 \\
Hasil biji kering (ku/ha) & 15,35 & 14,80 & 4,72 & 7,38 \\
\hline
\end{tabular}

Kelayakan Usahatani Kedelai dengan Pola Monokultur dan Polikultur

Analisis usahatani dilakukan untuk melihat kelayakan budidaya kedelai secara monokultur dan polikultur untuk setiap jenis kedelai (Tabel 2 dan 3).

Berdasarkan Tabel 2 dan 3, pengusahaan kedelai secara monokultur layak dilakukan, baik menggunakan kedelai varietas Anjasmoro maupun Dena 1. Tingkat produktivitas kedelai varietas Anjasmoro secara monokultur sebesar $15,35 \mathrm{ku} / \mathrm{ha}$. Dari Rp. 7.617.000/ha biaya produksi, biaya bahan atau sarana produksi yang dikeluarkan sebesar Rp. 4.669.500/ha (61,30\% dari biaya produksi) dan dengan tidak memperhitungan biaya tenaga kerja keluarga, biaya yang dikeluarkan untuk tenaga kerja sebesar Rp. 2.947.500/ha $(38,70 \%$ dari biaya produksi). Untuk menerapkan teknologi rekomendasi, biaya untuk pembelian pupuk adalah pengeluaran yang terbesar pada biaya sarana produksis. Sedangkan pada biaya tenaga kerja, aktivitas untuk panen dan pascapanen memerlukan pengeluaran terbesar. Jika dihitung dengan tingkat harga jual kedelai Rp. 7.800/kg, maka penerimaan hasil panen kedelai varietas Anjasmoro dan Dena 1 diperoleh masing-masing sebesar $\mathrm{Rp}$. 11.973.000/ha dan Rp. 11.544.000/ha. Dengan total biaya produksi kedelai varietas Anjasmoro dan Dena 1 masingmasing sebesar Rp. 7.617.000/ha dan Rp. 7.589.500/ha, maka diperoleh pendapatan bersih masing-masing Rp. 4.356.000/ha dan Rp. 3.954.500/ha. Efisiensi usahatani kedelai ini diperlihatkan dengan $\mathrm{R} / \mathrm{C}>1$ dan $\mathrm{B} / \mathrm{C}>0$. Budidaya kedelai secara monokultur Varietas Anjasmoro menghasilkan $\mathrm{R} / \mathrm{C}$ dan $\mathrm{B} / \mathrm{C}$ yang lebih tinggi dibandingkan dengan varietas Dena 1, yaitu R/C varietas Anjasmoro sebesar 1,57 dan R/C varietas Dena 1 sebesar 1,52 dan B/C Anjasmoro sebesar 0,57 dan B/C Dena 1 sebesar 0,52. Hal ini menunjukkan budidaya kedelai secara menonokultur menggunakan varietas Anjasmoro lebih menguntungkan dibandingkan varietas Dena 1.

Kelayakan usahatani budidaya kedelai yang ditanam secara polikultur di antara tanaman karet yang belum menghasilkan disajikan pada Tabel 4 dan 5 .

Hasil kajian menunjukkan bahwa produktivitas kedelai yang diperoleh dari sistem tumpangsari karet umur 3 tahun dan kedelai jauh lebih rendah dibandingkan dengan pertanaman monokultur. Namun demikian, parameter kelayakan usahatani $\mathrm{R} / \mathrm{C}$ dan $\mathrm{B} / \mathrm{C}$ masih menunjukkan nilai positif yang berarti usahatani ini layak untuk dilakukan oleh petani. Pada umur tanaman karet 3 tahun, dari 1 hektar tanaman karet, maka 50\% lahan diantara tanaman karet tersebut masih dapat digunakan untuk tanaman sela. Seperti halnya budidaya kedelai secara monokultur dengan rekomendasi pemupukan dan teknologi budidaya, maka pada pola karetkedelai inipun biaya sarana produksi lebih tinggi dibanding biaya tenaga kerja (tanpa memperhitungkan biaya bibit karet). Proporsi biaya sarana produksi mencapai $67,2-67,82 \%$ dan biaya tenaga kerja mencapai $32,2-32,8 \%$ dari total biaya produksi.

Hasil analisis ekonomi menunjukkan bahwa jika diasumsikan tingkat harga jual kedelai Rp. $7.800 / \mathrm{kg}$, maka penerimaan 
hasil panen kedelai varietas Anjasmoro dan Dena 1 yang ditumpangsarikan dengan tanaman karet sebesar Rp. 3.681.800/ha dan Rp. 5.756.400/ha. Dengan total biaya produksi kedelai varietas Anjasmoro dan Dena 1 masing-masing sebesar Rp. 3.592.000/ha dan Rp. 3.625.000/ha, maka diperoleh pendapatan bersih masing-masing Rp. 89.600/ha dan Rp. 2.131.400/ha. Efisiensi usahatani integrasi kedelai dan tanaman karet belum menghasilkan ini diperlihatkan dengan $\mathrm{R} / \mathrm{C}>1$ dan $\mathrm{B} / \mathrm{C}>0$. Kedelai varietas Dena 1 menghasilkan R/C dan $\mathrm{B} / \mathrm{C}$ yang lebih tinggi dibandingkan dengan varietas Anjasmoro yaitu R/C varietas Anjasmoro sebesar 1,02 dan R/C varietas Dena 1 sebesar 1,59 dan $B / C$ Anjasmoro sebesar 0,02 dan B/C Dena 1 sebesar 0,59. Parameter efisiensi usahatani integrasi kedelai dan tanaman karet belum menghasilkan umur 3 tahun ini menunjukkan kedelai varietas Dena 1 memberikan efisiensi ekonomi lebih tinggi dibandingkan dengan kedelai varietas Anjasmoro. Hal ini menunjukkan, bahwa dibandingkan dengan tanaman karet yang ditanam secara monokultur, tidak ditanami tanaman sela, maka dengan penanaman kedelai varietas Dena 1, petani memperoleh penambahan pendapatkan sebesar $\mathrm{Rp}$. 2.131.400/ha karet, dalam waktu 3 bulan, sedangkan bila ditanami tanaman sela kedelai varietas Anjasmoro, penambahan pendapatan yang diperoleh petani adalah sebesar Rp. 89.600/ha karet.

Tabel 2. Analisis usahatani monokultur kedelai varietas anjasmoro per ha

\begin{tabular}{|c|c|c|c|c|}
\hline Uraian & \multicolumn{2}{|c|}{ Volume } & Harga (Rp/Satuan) & Nilai (Rp) \\
\hline \multicolumn{5}{|l|}{ I.Sarana Produksi } \\
\hline Benih FS & 40 & $\mathrm{~kg}$ & 15.000 & 600.000 \\
\hline Pupuk kandang & 2.000 & $\mathrm{~kg}$ & 400 & 800.000 \\
\hline Dolomit & 1.000 & $\mathrm{~kg}$ & 1.000 & 1.000 .000 \\
\hline Urea & 25 & $\mathrm{~kg}$ & 2.200 & 55.000 \\
\hline TSP & 200 & $\mathrm{~kg}$ & 6.000 & 1.200 .000 \\
\hline $\mathrm{KCl}$ & 100 & $\mathrm{~kg}$ & 6.000 & 600.000 \\
\hline Rhizobium & 1 & Bks & 30.000 & 30.000 \\
\hline Herbisida & 1 & paket & 252.000 & 252.000 \\
\hline Insektisida & 1 & paket & 132.500 & 132.500 \\
\hline Biaya Sarana Produksi & & & & 4.669 .500 \\
\hline \multicolumn{5}{|l|}{ II. Tenaga kerja } \\
\hline Pembersihan gulma & 2 & HOK & 80.000 & 160.000 \\
\hline Pengolahan lahan & 1 & $\mathrm{Ha}$ & 800.000 & 800.000 \\
\hline Penanaman & 4 & $\mathrm{HOK}$ & 80.000 & 320.000 \\
\hline Pengendalian OPT & 4 & $\mathrm{HOK}$ & 50.000 & 200.000 \\
\hline Pemupukan & 4 & HOK & 50.000 & 200.000 \\
\hline Panen & 10 & $\mathrm{HOK}$ & 50.000 & 500.000 \\
\hline Pasca panen & 1.535 & $\mathrm{~kg}$ & 500 & 767.500 \\
\hline Biaya Tenaga Kerja & & & & 2.947 .500 \\
\hline III. Produksi (Penerimaan) & 1.535 & $\mathrm{~kg}$ & 7.800 & 11.973 .000 \\
\hline Jumlah Biaya Produksi & & & & 7.617 .000 \\
\hline Pendapatan & & & & 4.356 .000 \\
\hline $\mathrm{R} / \mathrm{C}$ & & & & 1,57 \\
\hline $\mathrm{B} / \mathrm{C}$ & & & & 0,57 \\
\hline
\end{tabular}


Tabel 3. Analisis usahatani monokultur kedelai varietas dena 1 per ha

\begin{tabular}{lrrrr}
\hline Uraian & \multicolumn{2}{l}{ Volume } & Harga (Rp/Satuan) & Nilai (Rp) \\
\hline I.Sarana Produksi & & & & 600.000 \\
\hline Benih FS & 40 & $\mathrm{~kg}$ & 15.000 & 800.000 \\
Pupuk kandang & 2.000 & $\mathrm{~kg}$ & 400 & 1.000 .000 \\
Dolomit & 1.000 & $\mathrm{~kg}$ & 1.000 & 55.000 \\
Urea & 25 & $\mathrm{~kg}$ & 2.200 & 1.200 .000 \\
TSP & 200 & $\mathrm{~kg}$ & 6.000 & 600.000 \\
KCl & 100 & $\mathrm{~kg}$ & 6.000 & 30.000 \\
Rhizobium & 1 & Bks & 30.000 & 252.000 \\
Herbisida & 1 & paket & 252.000 & 132.500 \\
Insektisida & 1 & paket & 132.500 & 4.669 .500 \\
Biaya Bahan & & & & \\
\hline II. Tenaga kerja & & & & 160.000 \\
Pembersihan gulma & 2 & HOK & 80.000 & 800.000 \\
Pengolahan lahan & 1 & Ha & 800.000 & 320.000 \\
Penanaman & 4 & HOK & 80.000 & 200.000 \\
Pengendalian OPT & 4 & HOK & 50.000 & 200.000 \\
Pemupukan & 4 & HOK & 50.000 & 500.000 \\
Panen & 10 & HOK & 50.000 & 740.000 \\
Pasca panen & 1.480 & $\mathrm{~kg}$ & 500 & 2.920 .000 \\
Biaya Tenaga Kerja & & & & 11.544 .000 \\
III.Produksi (Penerimaan) & 1.480 & $\mathrm{~kg}$ & 7.800 & 3.954 .500 \\
Jumlah Biaya Produksi & & & & 1,52 \\
Pendapatan & & & & 0,52 \\
R/C & & & & \\
B/C & & & & \\
\hline
\end{tabular}

Tabel 4. Analisis usahatani polikukultur kedelai varietas anjasmoro-karet per ha

\begin{tabular}{lrrrr}
\hline Uraian & \multicolumn{2}{c}{ Volume } & Harga (Rp/Satuan) & Nilai (Rp) \\
\hline I. Sarana Produksi & & & & 15.000 \\
\hline Benih FS & 20 & $\mathrm{~kg}$ & 400 & 300.000 \\
Pupuk kandang & 650 & $\mathrm{~kg}$ & 2.200 & 260.000 \\
Urea & 12,5 & $\mathrm{~kg}$ & 6.000 & 27.500 \\
TSP & 75 & $\mathrm{~kg}$ & 6.000 & 450.000 \\
KCl & 50 & $\mathrm{~kg}$ & 1.000 & 300.000 \\
Dolomit & 500 & $\mathrm{~kg}$ & 15.000 & 500.000 \\
Rhizobium & 0,5 & Bks & 413.000 & 15.000 \\
Herbisida & 1 & paket & 170.500 & 413.000 \\
Insektisida & 1 & paket & & 170.500 \\
Biaya Sarana Produksi & & & & 2.436 .000 \\
\hline II. Tenaga Kerja & & & & \\
\hline Pembersihan lahan & 2 & HOK & 80.000 & 160.000 \\
Penanaman & 2 & HOK & 50.000 & 160.000 \\
Pengendalian OPT & 4 & HOK & 50.000 & 200.000 \\
Pemupukan & 2 & HOK & 50.000 & 100.000 \\
Panen & 6 & HOK & 50.000 & 300.000 \\
Pasca panen & 472 & $\mathrm{~kg}$ & 500 & 236.000 \\
Biaya Tenaga Kerja & & & & 1.156 .000 \\
III. Produksi (Penerimaan) & & & 3.681 .600 \\
Jumlah Biaya Produksi & 472 & $\mathrm{~kg}$ & & 3.592 .000 \\
Pendapatan & & & & 89.600 \\
R/C & & & & 1,02 \\
B/C & & & & 0,02 \\
\hline
\end{tabular}


Tabel 5. Analisis usahatani polikukultur kedelai varietas dena 1-karetper ha

\begin{tabular}{|c|c|c|c|c|}
\hline Uraian & \multicolumn{2}{|c|}{ Volume } & Harga (Rp/Satuan) & Nilai (Rp) \\
\hline \multicolumn{5}{|l|}{ I. Sarana Produksi } \\
\hline Benih FS & 20 & $\mathrm{~kg}$ & 15.000 & 300.000 \\
\hline Pupuk kandang & 650 & $\mathrm{~kg}$ & 400 & 260.000 \\
\hline Urea & 12,5 & $\mathrm{~kg}$ & 2.200 & 27.500 \\
\hline TSP & 75 & $\mathrm{~kg}$ & 6.000 & 450.000 \\
\hline $\mathrm{KCl}$ & 50 & $\mathrm{~kg}$ & 6.000 & 300.000 \\
\hline Dolomit & 500 & $\mathrm{~kg}$ & 1.000 & 500.000 \\
\hline Rhizobium & 0,5 & Bks & 15.000 & 15.000 \\
\hline Herbisida & 1 & paket & 413.000 & 413.000 \\
\hline Insektisida & 1 & paket & 170.500 & 170.500 \\
\hline Biaya Sarana Produksi & & & & 2.436 .000 \\
\hline \multicolumn{5}{|l|}{ II. Tenaga kerja } \\
\hline Pembersihan lahan & 2 & $\mathrm{HOK}$ & 80.000 & 160.000 \\
\hline Penanaman & 2 & $\mathrm{HOK}$ & 80.000 & 160.000 \\
\hline Pengendalian OPT & 4 & $\mathrm{HOK}$ & 50.000 & 200.000 \\
\hline Pemupukan & 2 & $\mathrm{HOK}$ & 50.000 & 100.000 \\
\hline Panen & 5 & $\mathrm{HOK}$ & 50.000 & 200.000 \\
\hline Pasca panen & 738 & $\mathrm{~kg}$ & 500 & 369.000 \\
\hline Biaya Tenaga Kerja & & & & 1.189 .000 \\
\hline III. Produksi (Penerimaan) & 738 & $\mathrm{~kg}$ & 7.800 & 5.756 .400 \\
\hline Jumlah Biaya Produksi & & & & 3.625 .000 \\
\hline Pendapatan & & & & 2.131 .400 \\
\hline $\mathrm{R} / \mathrm{C}$ & & & & 1,59 \\
\hline $\mathrm{B} / \mathrm{C}$ & & & & 0,59 \\
\hline
\end{tabular}

\section{PEMBAHASAN}

Intensitas cahaya di antara tanaman karet dipengaruhi oleh beberapa faktor seperti jarak tanam karet, umur tanaman serta pengelolaan tanaman karet. Penanaman karet dengan jarak yang rapat dan umur tanaman yang tua akan memperkecil intensitas cahaya yang masuk. Selain itu, pengelolaan tanaman juga berpengaruh terhadap intensitas cahaya, dimana pengelolaan karet yang intensif akan memberikan pertumbuhan tanaman karet yang optimal (tajuk tumbuh normal) sehingga tentunya akan mengurangi cahaya yang masuk di antara gawangan karet.

Terdapat dua kriteria pengukuran cahaya yakni pada kondisi normal (cerah) dan pada kondisi mendung. Pada kondisi cerah intensitas cahaya berkisar antara 10.36468.736 lux, sedangkan pada kondisi mendung yakni 44.806-80.283 lux. Menurut Peter (2011), intensitas penyinaran matahari saat penyinaran langsung ialah 32.000-130.000 lux. Dengan kondisi ini, intensitas cahaya di lokasi kajian masih tergolong normal. Menurut Handriawan et al. (2016), intensitas cahaya matari 53.700 lux mengakibatkan penurunan hasil biji taksiran kedelai Dena 1 sebesar 17,41\% dan Anjasmoro sebesar 22,87\% serta Grobogan sebesar $12,33 \%$. Sedangkan intensitas cahaya 26.663 lux mengakibatkan penurunan hasil biji taksiran kedelai Dena 1 sebesar 34,38\%, Anjasmoro 45,74\%, serta Grobogan 23,79\%.

Berdasarkan Gambar 2, intensitas cahaya optimal yang masuk terutama terdapat pada bagian tengah kebun (jarak 40-60 m) dan berkurang pada jarak $20 \mathrm{~m}$ dan $80 \mathrm{~m}$. Variasi intensitas cahaya yang masuk juga dipengaruhi oleh pertumbuhan tajuk tanaman, dimana pada umumnya pada kondisi tanaman yang mempunyai tajuk rapat (besar), intensitas cahaya yang masuk sangat sedikit dibandingkan dengan tanaman yang memiliki tajuk kecil.

Sopandie et al. (2003) menyatakan bahwa adanya naungan tanaman karet dapat menyebabkan terjadinya etiolasi pada tanaman yang menjadi salah satu mekanisme yang dibangun tanaman agar 
dapat menangkap cahaya dalam jumlah yang banyak. Hasil ini sejalan dengan Taiz dan Zieger (1991) dalam Kristiono dan Subandi (2016) yang menyatakan tanaman yang tumbuh pada kondisi ternaungi akan menghasilkan auksin maksimum, sehinga menyebabkan batang tumbuh memanjang secara cepat dan sukulen.

Mimbar (1994) menambahkan cahaya sangat mempengaruhi morfologi tanaman kedelai karena menyebabkan perubahan terhadap umur pembungaan dan kemasakan yang dapat menimbulkan perbedaan dalam tinggi tanaman, jumlah polong, luas daun, kerebahan, dan banyak sifat-sifat lainnya termasuk hasil biji.Makin tinggi tingkat naungan maka akan menurunkan komponen-komponen pertumbuhan, kecuali tinggi tanaman (Fahmi, 2003).

Menurut Fikriati (2010), jumlah polong total, jumlah polong isi, dan jumlah polong hampa merupakan karakter yang berpengaruh langsung terhadap hasil per petak. Semakin banyak jumlah polong yang terbentuk maka kemungkinan hasil yang akan diperoleh juga semakin tinggi. Akan tetapi hal tersebut harus diimbangi dengan kemampuan polong yang telah terbentuk untuk mengisi biji. Selain itu juga jumlah polong yang dihasilkan akan sangat ditentukan oleh varietas kedelai. Hasil kajian memperlihatkan bahwa pada pola polikultur, jumlah polong total dan jumlah polong isi varietas Anjasmoro yang dihasilkan kedelai lebih rendah dibandingkan kedelai yang ditanam secara monokultur. Jumlah polong total dan jumlah polong isi kedelai varietas Anjasmoro sistem tumpangsari lebih rendah $42 \%$ dan $45 \%$ dibandingkan sistem monokultur. Penurunan jumlah polong dapat disebabkan karena adanya pengaruh naungan sehingga penerimaan cahaya oleh tanaman juga berkurang. Afriana (2003) menunjukkan kedelai pada intensitas cahaya rendah mengalami penurunan jumlah polong per batang dan jumlah polong isi. Sebelumnya, Putisari (2001) menyatakan bahwa rata-rata jumlah polong tanaman ternaungi lebih rendah dari tanaman yang tidak ternaungi. Namun demikian, pada varietas tertentu yang mempunyai toleransi terhadap kondisi naungan, jumlah polong yang dihasilkan tidak terlalu dipengaruhi oleh kurangnya intensitas cahaya. Hasil ini terlihat pada varietas Dena 1, dimana jumlah polong total dan jumlah polong isi yang ditanam secara polikultur ternyata lebih banyak (2\%) dibandingkan dengan pertanaman monokulturnya. Hasil ini sejalan dengan deksripsi varietas yang dikeluarkan oleh Balitkabi (2016), Dena 1 memiliki toleransi terhadap kondisi naungan hingga 50\%.

Keragaan tanaman dan hasil biji dipengaruhi faktor genetik dan lingkungan secara bersama-sama (Kuswantoro et al., 2017; Iqbal et al., 2010). Ditambahkan Kuswantoro et al. (2017), genotipe yang lebih tinggi atau ukuran biji lebih besar umumnya memiliki hasil biji lebih rendah sedangkan jumlah cabang, jumlah polong isi, dan jumlah biji yang banyak umumnya menghasilkan bobot biji lebih tinggi. Adanya faktor naungan pada pertanaman kedelai polikultur juga sangat mempengaruhi hasilnya. Pada fase generatif, tanaman yang kekurangan cahaya matahari akan mudah mengalami penurunan produktivitas, karena bunga dan polong mudah gugur (Jiang dan Egli, 1993 dalam Sundari dan Susanto, 2012). Menurut penelitian Adisarwanto et al. (2000), naungan $65 \%$ menurunkan hasil kedelai $34 \%$ pada musim kemarau dan $54 \%$ pada musim hujan. Ditambahkan Jufri (2006), tingkat naungan $75 \%$ bahkan dapat menurunkan hasil hingga 90\%. Oleh karenanya, dalam pengembangkan kedelai secara polikultur perlu diperhatikan beberapa faktor seperti umur tanaman penanung yang mempengaruhi intensitas cahaya maupun varietas kedelai yang ditanam.

Produktivitas kedelai yang lebih rendah pada kondisi ternanungi, belum berarti merugikan petani. Evaluasi keuntungan atau kerugian produktivitas lahan yang ditimbulkan dari pola polikultur tanaman kedelai dengan tanaman karet belum 
menghasilkan dibandingkan dengan pola tanam monokultur karet atau monokultur kedelai dilakukan dengan cara menghitung Nilai Kesetaraan Lahan (NKL) (Tabel 6). NKL menggambarkan suatu areal yang dibutuhkan untuk total produksi monokultur yang setara dengan satu ha produksi secara tumpangsari. Pada tanaman perkebunan kelapa sawit, tumpang sari kelapa sawit dan kedelai dapat mengoptimalkan pemanfaatan lahan, ditunjukkan oleh nisbah kesetaraan lahan (NKL) yang meningkat dari 1,0 menjadi 1,3-1,7 (Marwoto et al., 2012).

Tumpangsari tanaman pangan/tanaman lain yang berpotensi menguntungkan di lahan tanaman tahunan yang belum menghasilkan perlu dipertimbangkan sebagai alternatif pengembangan tanaman lain yang memiliki potensi lebih menguntungkan. Pada kondisi ini lahan masih terbuka dan pemanfaatan cahaya menjadi sangat tidak efisien karena energi cahaya matahari masih belum dimanfaatkan secara optimal.

Sistem polikultur melalui tumpangsari karet umur 3 tahun dengan kedelai memiliki nilai NKL lebih tinggi dibandingkan dengan pertanaman karet dengan sistem monokultur. Hal serupa ditunjukkan oleh Kristiono dan Subandi (2016), Tistama et al. (2016), Ogwuche et al. (2012). Hal ini menunjukkan bahwa sistem polikultur lebih berdaya guna dalam pemanfaatan lahan.

Analisis usahatani dilakukan untuk melihat kelayakan budidaya kedelai secara monokultur dan polikultur untuk setiap jenis kedelai. Analisis usahatani disajikan pada Tabel 2 dan 3.

Tabel 6. Nilai kesetaraan lahan (NKL) dalam hubungannya dengan varietas kedelai dan sistem polikultur

\begin{tabular}{lccc}
\hline \multirow{2}{*}{ Sistem Tanam } & \multicolumn{3}{c}{ Nilai Kesetaraan Lahan } \\
\cline { 2 - 4 } & $\begin{array}{c}\text { Berdasarkan Hasil } \\
\text { Produksil Getah } \\
\text { Karet (A) }\end{array}$ & $\begin{array}{c}\text { Berdasarkan Hasil } \\
\text { Biji Kering } \\
\text { Kedelai (B) }\end{array}$ & Total (A+B) \\
\hline Monokultur karet & - & - & - \\
Monokultur kedelai Anjasmoro & - & 1,00 & 1,00 \\
Monokultur kedelai Dena 1 & - & 1,00 & 1,00 \\
Polikultur karet + kedelai Anjasmoro & - & 0,31 & 0,31 \\
Polikultur karet + kedelai Dena 1 & - & 0,50 & 0,50 \\
\hline
\end{tabular}

Berdasarkan Tabel 2 dan 3, pengusahaan kedelai secara monokultur layak dilakukan, baik menggunakan kedelai varietas Anjasmoro maupun Dena 1. Tingkat produktivitas kedelai varietas Anjasmoro secara monokultur sebesar $15,35 \mathrm{ku} / \mathrm{ha}$. Dari Rp 7.617.000/ha biaya produksi, biaya bahan atau sarana produksi yang dikeluarkan sebesar $\mathrm{Rp}$ 4.669.500/ha (61,30\% dari biaya produksi) dan dengan tidak memperhitungan biaya tenaga kerja keluarga, biaya yang dikeluarkan untuk tenaga kerja sebesar $\mathrm{Rp}$ 2.947.500/ha $(38,70 \%$ dari biaya produksi). Untuk menerapkan teknologi rekomendasi, biaya untuk pembelian pupuk adalah pengeluaran yang terbesar pada biaya sarana produksis. Sedangkan pada biaya tenaga kerja, aktivitas untuk panen dan pascapanen memerlukan pengeluaran terbesar. Jika dihitung dengan tingkat harga jual kedelai Rp 7.800/kg, maka penerimaan hasil panen kedelai varietas Anjasmoro dan Dena 1 diperoleh masing-masing sebesar $\mathrm{Rp}$ 11.973.000/ha dan Rp 11.544.000/ha. Dengan total biaya produksi kedelai varietas Anjasmoro dan Dena 1 masingmasing sebesar Rp 7.617.000/ha dan Rp 7.589.500/ha, maka diperoleh pendapatan bersih masing-masing Rp 4.356.000/ha dan Rp. 3.954.500/ha.

Efisiensi usahatani kedelai ini diperlihatkan dengan $\mathrm{R} / \mathrm{C}>1$ dan $\mathrm{B} / \mathrm{C}>0$. Budidaya kedelai secara monokultur Varietas Anjasmoro menghasilkan R/C dan $\mathrm{B} / \mathrm{C}$ yang lebih tinggi dibandingkan dengan varietas Dena 1, yaitu $\mathrm{R} / \mathrm{C}$ varietas Anjasmoro sebesar 1,57 dan $\mathrm{R} / \mathrm{C}$ varietas Dena 1 sebesar 1,52 dan B/C Anjasmoro sebesar 0,57 dan B/C Dena 1 sebesar 0,52. 
Hal ini menunjukkan budidaya kedelai secara menonokultur menggunakan varietas Anjasmoro lebih menguntungkan dibandingkan varietas Dena 1. Kelayakan usahatani budidaya kedelai yang ditanam secara polikultur di antara tanaman karet yang belum menghasilkan disajikan pada Tabel 4 dan 5. Hasil kajian menunjukkan bahwa produktivitas kedelai yang diperoleh dari sistem tumpangsari karet umur 3 tahun dan kedelai jauh lebih rendah dibandingkan dengan pertanaman monokultur. Namun demikian, parameter kelayakan usahatani $\mathrm{R} / \mathrm{C}$ dan $\mathrm{B} / \mathrm{C}$ masih menunjukkan nilai positif yang berarti usahatani ini layak untuk dilakukan oleh petani. Pada umur tanaman karet 3 tahun, dari 1 hektar tanaman karet, maka 50\% lahan diantara tanaman karet tersebut masih dapat digunakan untuk tanaman sela. Seperti halnya budidaya kedelai secara monokultur dengan rekomendasi pemupukan dan teknologi budidaya, maka pada pola karetkedelai inipun biaya sarana produksi lebih tinggi dibanding biaya tenaga kerja (tanpa memperhitungkan biaya bibit karet). Proporsi biaya sarana produksi mencapai $67,2-67,82 \%$ dan biaya tenaga kerja mencapai $32,2-32,8 \%$ dari total biaya produksi.

Hasil analisis ekonomi menunjukkan bahwa jika diasumsikan tingkat harga jual kedelai Rp 7.800/kg, maka penerimaan hasil panen kedelai varietas Anjasmoro dan Dena 1 yang ditumpangsarikan dengan tanaman karet sebesar Rp 3.681.800/ha dan $\mathrm{Rp}$ 5.756.400/ha. Dengan total biaya produksi kedelai varietas Anjasmoro dan Dena 1 masing-masing sebesar $\mathrm{Rp}$ 3.592.000/ha dan Rp 3.625.000/ha, maka diperoleh pendapatan bersih masing-masing Rp 89.600/ha dan Rp. 2.131.400/ha. Efisiensi usahatani integrasi kedelai dan tanaman karet belum menghasilkan ini diperlihatkan dengan $\mathrm{R} / \mathrm{C}>1$ dan $\mathrm{B} / \mathrm{C}>0$. Kedelai varietas Dena 1 menghasilkan $\mathrm{R} / \mathrm{C}$ dan $\mathrm{B} / \mathrm{C}$ yang lebih tinggi dibandingkan dengan varietas Anjasmoro yaitu R/C varietas Anjasmoro sebesar 1,02 dan R/C varietas Dena 1 sebesar 1,59 dan $B / C$
Anjasmoro sebesar 0,02 dan B/C Dena 1 sebesar 0,59. Parameter efisiensi usahatani integrasi kedelai dan tanaman karet belum menghasilkan umur 3 tahun ini menunjukkan kedelai varietas Dena 1 memberikan efisiensi ekonomi lebih tinggi dibandingkan dengan kedelai varietas Anjasmoro. Hal ini menunjukkan, bahwa dibandingkan dengan tanaman karet yang ditanam secara monokultur, tidak ditanami tanaman sela, maka dengan penanaman kedelai varietas Dena 1, petani memperoleh penambahan pendapatkan sebesar $\mathrm{Rp}$ 2.131.400/ha karet, dalam waktu 3 bulan, sedangkan bila ditanami tanaman sela kedelai varietas Anjasmoro, penambahan pendapatan yang diperoleh petani adalah sebesar Rp 89.600/ha karet. Pada sistem tumpang sari kedelai di perkebunan kelapa sawit, usaha tani kedelai dengan menerapkan teknologi PTT layak dikembangkan karena memiliki nilai $\mathrm{B} / \mathrm{C}$ rasio 1,68, lebih tinggi dibandingkan nonPTT yang hanya 1,04 (Marwoto et al., 2012).

Berdasarkan hasil kajian ini, secara umum pola polikultur dengan integrasi tanaman kedelai-karet lebih menguntungkan dibandingkan dengan sistem monokultur karena produktivitas lahan menjadi lebih tinggi, jenis komoditas yang dihasilkan beragam, hemat dalam pemakaian sarana produksi dan risiko kegagalan panen dapat diperkecil (Turmudi, 2002). Disamping keuntungan di atas sistem tumpangsari dapat digunakan sebagai alat untuk konservasi lahan, pengendalian gulma, pengendalian hama dan penyakit tanaman, meningkatkan hasil tanaman, bahkan cara ini dapat mempertahankan kesuburan tanah bila salah satu jenis tanaman adalah tanaman kacangkacangan yang ditumpangsarikan dalam lahan (Yilmaz et al., 2008). Sistem tumpangsari juga membantu pertumbuhan karet terutama di areal-areal rehabilitasi (Idoko et al., 2012). Nugroho et al. (2010) melaporkan bahwa di areal gawangan yang tertutup kacang-kacangan menjadi lebih lembab karena aktivitas mikroba tanah 
meningkat. Kelembaban tanah ini membantu akar dalam menyerap hara dengan dibantu oleh aktivitas mikroba di sekitar perakaran.

\section{KESIMPULAN}

Keragaan pertumbuhan dan hasil dua varietas kedelai dengan pola monokultur lebih baik dibanding dengan polikultur. Produktivitas kedelai varietas Anjasmoro pertanaman monokultur mencapai 15,35 $\mathrm{ku} / \mathrm{ha}$, sedangkan dengan polikultur hanya menghasilkan biji kedelai 4,72 ku/ha. Sementara itu, produktivitas kedelai varietas Dena 1 sebesar 14,80 ku/ha dan dengan sistem tumpangsari menghasilkan biji kedelai 7,38 ku/ha. Akan tetapi, sistem polikultur memiliki nilai Nisbah Kesetaraan Lahan lebih tinggi dibandingkan dengan pertanaman karet dengan sistem monokultur. Artinya secara umum pola polikultur dengan mengintegrasikan tanaman kedelai dengan tanaman karet belum menghasilkan lebih menguntungkan dibandingkan dengan sistem monokultur karena produktivitas lahan menjadi lebih tinggi.

Budidaya kedelai secara monokultur maupun polikultur di antara tanaman karet belum menghasilkan (umur 3 tahun) layak untuk dilaksanakan dengan nilai $\mathrm{R} / \mathrm{C}>1$. Kedua varietas yang dibudidayakan dengan pola monokultur dan polikultur memberikan nilai R/C yang berbeda, dimana varietas kedelai Anjasmoro dan Dena 1 monokultur mempunyai R/C berturut-turur 1,57 dan 1,52. Sementara, pola polikultur karet dengan kedelai Anjasmoro maupun Dena 1 menghasilkan $\mathrm{R} / \mathrm{C}$ yakni 1,02 dan 1,59.

\section{DAFTAR PUSTAKA}

Adisarwanto T, Suhartina, Soegiyatni. 2000. Respon kedelai terhadap beberapa tingkat naungan. Edisi Khusus Balitkabi 16:12-21.

Afriana M. 2003. Studi Karakter Morfologi dan Anatomi Tanaman Kedelai (Glycine max) pada Beberapa Taraf Naungan Buatan. Skripsi. Program Sarjana, Institut Pertanian Bogor. Bogor. 46 hal.

Balitkabi (Balai Penelitian Tanaman Kacang-kacangan dan Umbi-umbian). 2016. Deskripsi Varietas Unggul Kedelai.

Badan Pusat Statistik Propinsi Sumatera Selatan. 2017. Sumatera Selatan dalam Angka. BPS Propinsi Sumatera Selatan. Palembang.

Chozin MA, Sopandie D, Sastrosumajo S, Sumarno. 1999. Physiology and genetic upland rice adaptation to shade. Laporan Graduate Team Research Grant, Proyek URGE). Jakarta. Direktorat Jenderal Pendidikan Tinggi.

Fahmi ZI. 2003. Iklim mikro dan pengaruhnya terhadap pertumbuhan produksi dan daya adaptasi genotipegenotipe kedelai (Glycine max (L.) Merr.) pada empat tingkat naungan buatan. Skripsi. Program Sarjana, Institut Pertanian Bogor. Bogor. 76 hal.

Fikriati M. 2010. Uji daya hasil lanjutan kedelai (Glycine max (1.) Merr.) toleran naungan di bawah tegakan karet rakyat di Kabupaten Sarolangun, Jambi. Skripsi. Institut Pertanian Bogor. 68 hal. Handriawan A, Respatie DW, Tohari. 2016. Pengaruh intensitas naungan terhadap pertumbuhan dan hasil tiga kultivar kedelai (Glycine $\max$ (L.) Merrill) di lahan pasir Pantai Bugel, Kulon Progo. J. Vegetalika. 5(3):1-14.

Idoko SO, Ehigiator JO, Esekhade TU, Orimoloyo JR. 2012. Rubber, maize and cassava Intercropping systems on rehabilitated rubber plantation soil in south eastern Nigeria. J. of Agric. and Biodiv. Res. 1(6): 97-101.

Iqbal Z, Arshad M, Ashraf M, Naeem R, Malik MF, Waheed A. 2010. Genetic divergence and correlation studies of soybean [Glycine $\max$ (L.) Merrill] Genotypes. Pakistan J. Bot. 42:971-976.

Janska A, Marsik P, Zelenkova S, Ovesna J. 2009. Cold stress and acclimation what is important for metabolic adjustment? 
Annual Review of Plant Biology. 12 pp. 395-405.

Kosma C, Triantafyllidis, Papasavvas V, Salahas A, Patakas G. 2013. Yield and nutritional quality of greenhouse lettuce as affected by shading and cultivation season. Emir. J Food Agric. 12:974-979.

Kristiono A, Subandi. 2016. Pengaruh penataan tanaman terhadap pertumbuhan dan hasil tumpangsari kedelai dan jagung pada lahan kering iklim kering. Prosiding Seminar Nasional Hasil Penelitian Tanaman Aneka Kacang dan Umbi, Malang, 19 Mei 2015. Puslitbang Tanaman Pangan, Bogor.

Kuswantoro H, Sutrisno, Supeno A. 2017. Keragaan Agronomi Galur-galur Kedelai Potensial pada Dua Agroekologi Lahan Kering Masam. J. Agron. Indonesia. 45(1):23-29.

Marwoto, Taufiq A, Suyamto. 2012. Potensi pengembangan tanaman kedelai di perkebunan kelapa sawit. J. Litbang Pertanian. 31(4): 169-174.

Mimbar SM. 1994. Pengaruh pola tumpang sari ubi kayu adira 1 dan kedelai orba terhadap retensi polong dan hasil kedelai orba. Fakultas Pertanian, Universitas Brawijaya. Malang. 139 hal.

Nugroho PA, Istianto, Siagian N, Karyudi. 2010. Pengaruh penanaman Mucuna bracteata terhadap status hara dan pertumbuhan tanaman karet belum menghasilkan. J Penelitian Karet. 28(1): 44-54.

Ogwuche P, Umar HY, Esekhade TU, Franscis SY. 2012. Economic of intercropping natural rubber with arable crops: A Panacea for poverty allevation of rubber farmers. J Agric. Soc. Sci. 8: 100-102.

Peter H. 2011. Measuring Light. Ryerson University.

Putisari M. 2001. Kandungan Karotenoid, Pertumbuhan, dan Produksi Beberapa Genotipe Kedelai (Glycine max (L.) Merrill.) pada Intensitas Cahaya Rendah. Skripsi. Program Sarjana, Institut Pertanian Bogor. Bogor. 65 hal.
Sopandie D, Chozin MA, Sastrosumarjo S, Juhaeti T, Sahardi. 2003. Toleransi padi gogo terhadap naungan. Hayati. 10:7175

Sopandie D, Kisman, Khumaida N, Trikoesoemaningtyas, Sobir. 2007. Karakter morfo-fisiologi daun, penciri adaptasi kedelai terhadap intensitas cahaya rendah. Bul. Agron. 35(2):96102.

Sundari T, Susanto GWA. 2012. Tingkat Adaptasi Beberapa Varietas Kedelai terhadap Naungan. $J$ Penelitian Tanaman Pangan. 31(2): 124-130.

Susanto GWA, Sundari T. 2010. Penampilan varietas unggul kedelai di lingkungan naungan buatan. Prosiding Seminar Hasil Penelitian Tanaman Aneka Kacang dan Umbi 2010, Malang.

Taufiq A, Marwoto, Rozi F, Jana Mejaya IM. 2009. Peningkatan Produksi Kedelai di Sumatera Selatan. Balitkabi. Puslitbangtan. Badan Litbang Pertanian.

Tistama R, Dalimunthe CI, Sembiring YRV, Fauzi IR, Hastuti RD, Suharsono. 2016. Tumpangsari Sorgum dan Kedelai untuk Mendukung Produktivitas Lahan Karet TBM (Hevea brasiliensis Muell Arg). Jurnal Penelitian Karet. 34(1):6176.

Turmudi E. 2002. Kajian Pertumbuhan dan Hasil Tanaman dalam Sistem Tumpangsari Jagung dengan Empat Kultivar Kedelai pada Berbagai Waktu Tanam. Jurnal Ilmu-ilmu Pertanian Indonesia. 4(2):89-96

Yilmaz F, Atak M, Erayman M. 2008. Identification of Advantages of MaizeLegume Intercropping over Solitary Cropping through Competition Indices in the East Mediterranean Region Turk. Journal Agriculture and Forestry. 32: 111-119.

Zakaria AK. 2010. Kebijakan pengembangan budidaya kedelai menuju swasembada melalui partisipasi petani. Analisis Kebijakan. 8(3):259-272. 